\title{
Prevalence of posterior crossbite among pacifier users: a study in the deciduous dentition
}

\author{
Prevalência de mordida cruzada posterior em \\ usuários de chupeta: um estudo na dentadura \\ decídua
}

\begin{abstract}
Helio Scavone-Junior(a)
Rívea Inês Ferreira ${ }^{(a)}$

Tadeu Evandro Mendes(b)

Flávio Vellini Ferreira ${ }^{(c)}$
\end{abstract}

(a) Associate Professors; (b)Research Fellow; (c) Professor and Chairman - Department of Pediatric Dentistry and Orthodontics, University of São Paulo City (UNICID).
Received for publication on May 04, 2006 Sent for alterations on Aug 18, 2006 Accepted for publication on Nov 27, 2006

\begin{abstract}
The aim of this study was to evaluate the prevalence of posterior crossbite among children whose pacifier-sucking habit persisted until different ages. Children aged 3 to 6 years were randomly selected from public preschools in São Paulo, SP, Brazil. Their mothers were asked to complete a questionnaire on non-nutritive sucking behaviors. The sample consisted of 366 children assigned to 2 groups: control $(n=96)$ and pacifier users $(n=270)$. Pacifier users were further assigned to 3 subgroups, according to the age of habit persistence: P1 - until 2 years of age; P2 - between 2 and 4 years of age; and P3 - between 4 and 6 years of age. One dentist assessed the children for occlusal relationships through clinical examination. Associations between the age interval of habit discontinuation and the prevalence of posterior crossbite were analyzed using the chi-square test $(\mathrm{p}<0.05)$. The prevalence of posterior crossbite was significantly higher among pacifier users $(20.4 \%)$, compared to control children $(5.2 \%)$, p < 0.01 . Unilateral posterior crossbite was more prevalent than bilateral crossbite among pacifier users (9.8\% versus $3.6 \%$ ). Functional posterior crossbites were diagnosed in $3.1 \%$ of the control children and $7 \%$ of the pacifier users. The frequencies of posterior crossbite were notably high for children in the 3 pacifier subgroups, $\mathrm{P} 1, \mathrm{P} 2$, and $\mathrm{P} 3$, corresponding to $17.2 \%, 16.9 \%$, and $27.3 \%$, respectively. The high prevalence of posterior crossbite may be associated with pacifiersucking habits that persisted after 2 years of age.
\end{abstract}

Descriptors: Malocclusion; Dentition, primary; Sucking behavior.

Resumo: O objetivo deste estudo foi avaliar prevalência de mordida cruzada posterior em crianças com hábito de sucção de chupeta que persistiu até diferentes idades. Crianças dos 3 aos 6 anos de idade foram aleatoriamente selecionadas de pré-escolas públicas em São Paulo, SP, Brasil. Solicitou-se às mães que respondessem a um questionário sobre hábitos de sucção não-nutritivos. A amostra consistiu de 366 crianças distribuídas em 2 grupos: controle $(\mathrm{n}=96)$ e usuários de chupeta $(\mathrm{n}=270)$. Os usuários de chupeta foram, então, separados em 3 subgrupos de acordo com a idade de persistência do hábito: P1 - até 2 anos de idade; P2 - entre 2 e 4 anos de idade e P3 - entre 4 e 6 anos de idade. Um cirurgiãodentista avaliou a oclusão das crianças por exame clínico. As associações entre intervalo de interrupção do hábito e prevalência de mordida cruzada posterior foram analisadas pelo teste Qui-Quadrado $(\mathrm{p}<0,05)$. A prevalência de mordida cruzada posterior foi significativamente mais elevada em usuários de chupeta $(20,4 \%)$, em comparação às crianças controles $(5,2 \%), p<0,01$. A mordida cruzada posterior unilateral foi mais prevalente do que a bilateral em usuários de chupeta $(9,8 \%$ versus $3,6 \%)$. As mordidas cruzadas posteriores funcionais foram diagnosticadas em $3,1 \%$ das crianças controles e $7 \%$ dos usuários de chupeta. As freqüências de mordida cruzada posterior foram notavelmente elevadas nos 3 subgrupos de usuários de chupeta, P1, P2 e P3, correspondendo a 17,2\%, 16,9\% e $27,3 \%$, respectivamente. A alta prevalência de mordida cruzada posterior pode estar associada com hábitos de sucção de chupeta que persistiram além dos 2 anos de idade. Descritores: Maloclusão; Dentição primária; Comportamento de sucção. 


\section{Introduction}

Many factors may be implicated in the etiology of posterior crossbite and much attention has been drawn to the non-nutritive sucking habits. ${ }^{8-}$ 10,16,17 An increased prevalence of posterior crossbite in pacifier users has been reported by several authors. ${ }^{1,2,6,8,17,18,22-24}$ Although many studies clearly demonstrated that prolonged non-nutritive sucking habits have a negative influence on occlusion in the deciduous dentition, , $2,14-17,21-24_{\text {few investigations }}$ have been carried out to analyze the association between the cessation of such habits at different ages and the development of malocclusions.

Thus, the aim of this study was to evaluate the prevalence of posterior crossbite among children who discontinued their pacifier-sucking habit until 2 years of age, between 2 and 4 years of age, and between 4 and 6 years of age. The null hypothesis stated no relationship exists between pacifier use discontinuation at different age intervals and the prevalence of posterior crossbite.

\section{Material and Methods}

This cross-sectional study is in agreement with Resolution 196/96, Brazilian National Committee of Health.

The present epidemiological investigation was conducted in public preschools in the eastern region of the city of São Paulo, SP, Brazil. Of 5 public preschools contacted, 3 agreed to participate in this research. Thus, the sample population consisted of mothers and their children randomly selected from these 3 public preschools. A total of 693 mothers of children aged 3 to 6 years, both genders, were asked to complete a questionnaire on non-nutritive sucking habits. Written informed consent was obtained from all participants' parents or legal guardians.

The mothers were asked whether their children had regularly sucked on pacifiers and, if so, at what age the habit was discontinued. Information about the type of pacifier (conventional or "orthodontic") was not collected, since previous studies demonstrated no clinically significant differences between children who sucked on conventional pacifiers and those who used "orthodontic" ones, as far as the transverse occlusal relationship is concerned.1,2,24
Children with digit-sucking habits were not included. Another criterion for sample selection was the absence of abnormal pressure habits over the craniofacial complex, such as the repetitive pressure of one hand over one side of the face, while the child is watching television, reading, studying and/or sleeping, since the persistence of these habits could also predispose to posterior crossbite. ${ }^{7,15}$

A previously calibrated and well-trained orthodontist, who was blinded to the questionnaire data, performed all clinical examinations in classroom settings under artificial light. During the clinical examination, the children were asked to sit in an upright position and bite in maximal intercuspation.

Children were selected based on a requirement that included all deciduous teeth present without cavitated carious lesions that could interfere with the occlusion assessments in the transverse plane. Children having one or more permanent teeth erupted or in eruption were excluded, since the purpose of this study was to relate posterior crossbite in the deciduous dentition to the duration of pacifier-sucking habit. The present study comprised presumably healthy children, without mouth breathing, orofacial clefts, or any other developmental anomalies that could contribute to the establishment of a posterior crossbite.

In this study, posterior crossbite was defined as a transverse discrepancy in the arches relationship in which the palatal cusps of one or more of the maxillary posterior teeth do not occlude in the central fossae of the opposing mandibular teeth. ${ }^{14}$ Therefore, a posterior crossbite was recorded whenever one maxillary deciduous canine and/or at least one maxillary deciduous molar occluded palatally to the buccal cusp of the opposing mandibular tooth. This reverse relationship was classified as unilateral or bilateral. Another variant comprises the so-called functional posterior crossbites, resulting from the mandible shifting into an abnormal position due to the presence of tooth interferences, frequently involving the deciduous canines. Functional crossbites are typically associated with mild bilateral constriction of the maxillary arch, which forces the mandible to displace laterally to a position that is more comfortable for the child. ${ }^{14}$ 
The sample consisted of 366 children who met the inclusion requirements. Approximately $47 \%$ of the children were excluded because (1) the questionnaires were not properly answered, (2) a history of digit-sucking and abnormal pressure habits was reported, (3) the children had undergone or were undergoing orthodontic treatment, (4) the mothers did not sign the written consent form, (5) the children refused to participate during the clinical examination, and (6) the children did not meet the clinical inclusion criteria.

Children were assigned to 2 groups: control $(\mathrm{n}=96)$ and pacifier users $(\mathrm{n}=270)$. The control group comprised children who had never sucked on a pacifier or a finger. To investigate the association between the prevalence of posterior crossbite and the age interval at which pacifier use was discontinued, children with a history of pacifier-sucking habit were further categorized into 3 subgroups: P1 - pacifier use persisted until 2 years of age; P2 - pacifier use was discontinued between 2 and 4 years of age; and $\mathrm{P} 3$ - pacifier use was discontinued between 4 and 6 years of age (Table 1 ).

Two-dimensional cross-tabulation was performed on questionnaire information versus clinical data. Combined data were submitted to the chi-square test to analyze possible associations between the prevalence of posterior crossbite and pacifier-sucking hab- its, considering the age interval at which pacifier use was discontinued. Significance was predetermined at $\mathrm{p}<0.05$.

\section{Results}

The prevalence of posterior crossbite according to duration of pacifier-sucking habit is shown in Table 2. Posterior crossbite was more frequently diagnosed among pacifier users, especially among children whose pacifier-sucking habit was discontinued between 4 and 6 years of age $(27.3 \%)$. Children whose pacifier-sucking habit persisted until the age of 2 years, as well as those who discontinued pacifier use between 2 and 4 years of age, had an increased prevalence of posterior crossbite; but children whose pacifier-sucking habit was ceased between 4 and 6 years of age had by far the highest prevalence. It should be noted that the prevalence of posterior crossbite in pacifier users was approximately 4 times as high as that observed for the control children ( $20.4 \%$ versus $5.2 \%$ ).

Table 3 shows data on the types of posterior crossbite for control children and pacifier users. Unilateral posterior crossbite, compared to the bilateral one, was more prevalent among pacifier users, as frequencies of $9.8 \%$ and $3.6 \%$, respectively, were recorded. The prevalence of unilateral posterior crossbite was found to be higher for children whose pacifier-suck-

Table 1 - Sample distribution according to gender and pacifier use.*

\begin{tabular}{|c|c|c|c|c|c|}
\hline Gender & Control & $\begin{array}{l}\text { P1 - Pacifier use persisted } \\
\text { until } 2 \text { years of age }\end{array}$ & $\begin{array}{l}\text { P2 - Pacifier use was discontinued } \\
\text { between } 2 \text { and } 4 \text { years of age }\end{array}$ & $\begin{array}{l}\text { P3 - Pacifier use was discontinued } \\
\text { between } 4 \text { and } 6 \text { years of age }\end{array}$ & Total \\
\hline Male & 44 (12) & $50(13.7)$ & $37(10.1)$ & $44(12)$ & 175 \\
\hline Female & 52 (14.2) & 49 (13.4) & $46(12.6)$ & $44(12)$ & $191 \quad(52.2)$ \\
\hline Total & $96(26.2)$ & $99(27.1)$ & $83(22.7)$ & $88(24)$ & $366(100)$ \\
\hline
\end{tabular}

*Data are presented as $\mathrm{n}$ (\% of total sample).

Table 2 - Prevalence of posterior crossbite by pacifier use.

\begin{tabular}{c|c|c|c|c|c}
\hline $\begin{array}{c}\text { Posterior Crossbite } \\
(\text { Yes/No) }\end{array}$ & $\begin{array}{c}\text { Control } \\
(\mathrm{n}=96)\end{array}$ & $\begin{array}{c}\text { P1 - Pacifier use } \\
\text { persisted until 2 years } \\
\text { of age }(\mathrm{n}=99)\end{array}$ & $\begin{array}{c}\text { P2 - Pacifier use was } \\
\text { discontinued between 2 and 4 } \\
\text { years of age }(\mathrm{n}=83)\end{array}$ & $\begin{array}{c}\text { P3 - Pacifier use was } \\
\text { discontinued between 4 and 6 } \\
\text { years of age }(\mathrm{n}=88)\end{array}$ & $\begin{array}{c}\text { Pacifier users } \\
(\mathrm{n}=270)\end{array}$ \\
\hline Yes & $5.2 \%$ & $17.2 \%$ & $16.9 \%$ & $27.3 \%$ & $20.4 \%$ \\
\hline No & $94.8 \%$ & $82.8 \%$ & $83.1 \%$ & $72.7 \%$ & $79.6 \%$ \\
\hline Total & $100 \%$ & $100 \%$ & $100 \%$ & $100 \%$ & $100 \%$ \\
\hline
\end{tabular}


Table 3 - Percentages of the types of posterior crossbite by pacifier use.

\begin{tabular}{l|c|c|c|c|c}
\hline $\begin{array}{c}\text { Posterior } \\
\text { Crossbite }\end{array}$ & Control & $\begin{array}{c}\text { P1 - Pacifier use persisted } \\
\text { until 2 years of age }\end{array}$ & $\begin{array}{c}\text { P2 - Pacifier use was discontinued } \\
\text { between 2 and 4 years of age }\end{array}$ & $\begin{array}{c}\text { P3 - Pacifier use was discontinued } \\
\text { between } 4 \text { and } 6 \text { years of age }\end{array}$ & $\begin{array}{c}\text { Pacifier } \\
\text { users }\end{array}$ \\
\hline Unilateral & 1.1 & 11.2 & 6.1 & 11.4 & 9.8 \\
\hline Bilateral & 1 & 3 & 2.4 & 5.7 & 3.6 \\
\hline Functional & 3.1 & 3 & 8.4 & 10.2 & 7 \\
\hline
\end{tabular}

Table 4 - Association between prevalence of posterior crossbite and pacifier use.

\begin{tabular}{l|c|c}
\hline \multirow{2}{*}{ Comparison between groups } & \multicolumn{2}{|c}{ Posterior Crossbite } \\
\cline { 2 - 3 } & $\left(\chi^{2}\right)^{*}$ & $p$ value \\
\hline $\begin{array}{l}\text { Control versus P1 - Pacifier use persisted } \\
\text { until 2 years of age }\end{array}$ & 5.83 & 0.02 \\
\hline $\begin{array}{l}\text { Control versus P2 - Pacifier use was } \\
\text { discontinued between 2 and 4 years of age }\end{array}$ & 5.21 & 0.02 \\
\hline $\begin{array}{l}\text { Control versus P3 - Pacifier use was } \\
\text { discontinued between 4 and 6 years of age }\end{array}$ & 15.21 & 0.00 \\
\hline \begin{tabular}{l} 
Control versus Pacifier users \\
\hline
\end{tabular}
\end{tabular}

${ }^{*}\left(\chi^{2}\right)$ indicates chi-square values.

ing habit persisted until 2 years of age $(11.2 \%)$ and for those who discontinued pacifier use between 4 and 6 years of age $(11.4 \%)$. The frequencies of functional posterior crossbites were greater among children who discontinued pacifier use between 2 and 4 years of age $(8.4 \%)$, as well as between 4 and 6 years of age $(10.2 \%)$, in comparison to control children $(3.1 \%)$ and to those whose pacifier-sucking habit persisted until 2 years of age $(3 \%)$.

As demonstrated in Table 4, posterior crossbite was significantly more prevalent in pacifier users with persisting non-nutritive sucking habits until 2 years of age and those having their habits ceased between 2 and 4 years of age, compared to control children $(\mathrm{p}=0.02)$. Nevertheless, there was a highly significant difference between control children and pacifier users whose non-nutritive sucking habit was discontinued between 4 and 6 years of age $(\mathrm{p}<0.01)$.

\section{Discussion}

The pacifier-sucking habit is very common in many western countries. ${ }^{11}$ In a Brazilian study of 650 mother-infant pairs, Victora et al..$^{20}$ (1997) reported that approximately $85 \%$ of infants were already us- ing pacifiers at the age of 1 month. Pacifier use is common both in the hospital and during the early months of life, when non-nutritive sucking habits are useful in helping to calm infants. ${ }^{4}$ However, an increased prevalence of posterior crossbite has been observed among children with non-nutritive sucking habits at the age of 2 years or older. ${ }^{16,22,23}$ It has been suggested that the type of non-nutritive sucking habit per se seems to influence the transverse disharmony. ${ }^{13,17,18,22,23}$ Posterior crossbite was more frequently diagnosed among pacifier users than among digit-suckers. $^{22,23}$

The decision as to when and how, or even whether, to treat posterior crossbite in the deciduous dentition is a controversial issue. Early treatment of posterior crossbites has been recommended due to the fact that these malocclusions are transferred to the permanent dentition in many cases, ${ }^{6,7,12,19}$ and that posterior crossbite might lead to progressive mandibular dysfunction and, maybe, even craniofacial asymmetry. ${ }^{6,12,18}$ It has also been suggested that the later the posterior crossbite is treated, the greater is the risk of damaging the temporomandibular joint. Another reason for early treatment of posterior crossbite is that in the transverse dimension, growth slows down earlier than in the sagittal or vertical dimension. In fact, it is uncertain as to how much spontaneous correction of the posterior crossbite may be expected.,14,16 In different countries and decades, frequency estimates of posterior crossbite vary between $5 \%$ and $26 \%$ or greater, depending on the prevalence and duration of nonnutritive sucking habits. ${ }^{2,3,5,6,8,16-18,22-24}$ The epidemiological association between pacifier-sucking habit and posterior crossbite has been documented by many authors. ${ }^{1,2,8,16,17,22,24}$ Larsson $^{8}$ (1986) reported that the prevalence of posterior crossbite was 5 times as high among 4-year-old pacifier users, when 
compared to children with no previous non-nutritive sucking habits. In a study conducted by Adair $e t$ al. ${ }^{2}$ (1995), posterior crossbite was diagnosed in $15 \%$ of the pacifier users, and, in contrast, in $5.1 \%$ of the control children. Zardetto et al. ${ }^{24}$ (2002) diagnosed posterior crossbite only in pacifier users.

Some authors have addressed the relationship between infant feeding methods and posterior crossbite. ${ }^{5,10,21,22}$ Viggiano et al. ${ }^{21}$ (2004) observed that children with non-nutritive sucking habits and those who were bottle-fed had a twofold risk of developing posterior crossbite. Conversely, Karjalainen et al. ${ }^{5}$ (1999) found neither posterior crossbite nor large overjet to be associated with non-nutritive sucking habits. When comparing distinct samples, however, the results must be interpreted with caution because there are cultural differences in feeding methods, as well as in non-nutritive sucking behaviors.

This study reported a greater prevalence of posterior crossbite among pacifier users in the deciduous dentition (20.4\%), when compared to other studies. ${ }^{2,3,8,10,24}$ Of the 366 children examined, $73.8 \%$ had pacifier-sucking habit. Based on data shown in Table 4, the pacifier-sucking habit was significantly associated with the presence of posterior crossbite. Caglar et al. ${ }^{3}$ (2005) reported some data on non-nutritive sucking habits and prevalence of malocclusions in the deciduous dentition, involving 7 countries. Remarkably, data from Porto Alegre, a city in southern Brazil, confirmed a high prevalence of pacifier use among Brazilian children (82\%), when compared to data from other countries, e.g. Niigata - Japan $(0 \%)$, Mexico City - Mexico (5\%), and Iowa City - USA $(43 \%)$. Among Brazilian children, $13 \%$ had posterior crossbite. Considering the high percentage of pacifier users in the Brazilian sample, it can be inferred that there is a strong association between pacifier-sucking habit and posterior crossbite.

Most cases of posterior crossbite in the deciduous dentition appear to be unilateral rather than bilateral. ${ }^{1,2,6,14,16,18}$ As in previous studies, unilateral posterior crossbite was more prevalent among pacifier users. Relatively low prevalences of bilateral posterior crossbite were recorded for both the control children (1\%) and the pacifier users $(3.6 \%)$. The present study highlighted the clinical importance of the association between the duration of pacifier use and the prevalence of posterior crossbite ( $\mathrm{Ta}$ bles 2 and 4). The findings of this investigation are in agreement with those reported by Warren, Bishara $^{22}$ (2002). The prevalence of posterior crossbite was higher as the duration of pacifier-sucking habit increased. Even the children with shorter pacifiersucking habit duration, i.e. pacifier use that persisted until 2 years of age, showed a significant difference from those having no habits (Table 4).

There are some limitations in interpreting the findings of the present research. The retrospective nature of this investigation did not avoid recall bias. Actually, the collecting of data on non-nutritive sucking behaviors relied on parental recall of information. However, the young age of the children enhanced the likelihood that the information regarding the cessation of non-nutritive sucking habits was reliable.

Data on frequency and intensity of non-nutritive sucking behaviors were not collected. The reported number of hours of pacifier use per day, termed "intensity" in some studies, was positively correlated with the presence of posterior crossbite. ${ }^{13,16}$ Nevertheless, in a more recent publication, no relationship between hours of use per day and any aspect of the occlusion in the deciduous dentition was found. ${ }^{2}$ Furthermore, data on pacifier-sucking "intensity" would be even more prone to recall bias.

The statistical method employed in this study tested the association between variables, irrespective of the possible interactions among them. However, given the great frequency of pacifier-sucking habit and the high prevalence of posterior crossbite, it can be stated that pacifier use might have been a relevant factor in the etiology of this malocclusion.

More importantly from a clinical perspective, the present study reported a relatively high prevalence of posterior crossbite among children whose pacifier-sucking habit persisted until 2 years of age $(17.2 \%)$. This is a dental health problem that should be carefully considered, since it is difficult to predict whether, and to what extent, these transverse disharmonies will persist into the mixed and permanent dentitions. In accordance with a study by Modéer et al. ${ }^{16}$ (1982), the results also indicated that pacifier use should be controlled starting at the 
age of 2 years to reduce the possibility of posterior crossbite development.

\section{Conclusions}

1. The high prevalence of posterior crossbite observed in the present study may be associated

\section{References}

1. Adair SM, Milano M, Dushku JC. Evaluation of the effects of orthodontic pacifiers on the primary dentitions of 24- to 59-month-old children: preliminary study. Pediatr Dent. 1992;14(1):13-8.

2. Adair SM, Milano M, Lorenzo I, Russell C. Effects of current and former pacifier use on the dentition of 24- to 59-monthold children. Pediatr Dent. 1995;17(7):437-44.

3. Caglar E, Larsson E, Andersson EM, Hauge MS, Ogaard B, Bishara $\mathrm{S}$ et al. Feeding, artificial sucking habits, and malocclusions in 3-year-old girls in different regions of the world. J Dent Child. 2005;72(1):25-30.

4. Howard CR, Howard FM, Lanphear B, Eberly S, deBlieck EA, Oakes D et al. Randomized clinical trial of pacifier use and bottle-feeding or cupfeeding and their effect on breastfeeding. Pediatrics. 2003;111(3):511-8.

5. Karjalainen S, Rönning O, Lapinleimu H, Simell O. Association between early weaning, non-nutritive sucking habits and occlusal anomalies in 3-year-old Finnish children. Int J Paediatr Dent. 1999;9(3):169-73.

6. Kurol J, Berglund L. Longitudinal study and cost-benefit analysis of the effect of early treatment of posterior cross-bites in the primary dentition. Eur J Orthod. 1992;14(3):173-9.

7. Kutin G, Hawes RR. Posterior cross-bites in the deciduous and mixed dentitions. Am J Orthod. 1969;56(5):491-504.

8. Larsson E. Effect of dummy-sucking on the prevalence of posterior cross-bite in the permanent dentition. Swed Dent J. 1986;10(3):97-101.

9. Larsson E. Prevalence of crossbite among children with prolonged dummy- and finger-sucking habit. Swed Dent J. 1983;7(3):115-9.

10. Larsson E. Sucking, chewing, and feeding habits and the development of crossbite: a longitudinal study of girls from birth to 3 years of age. Angle Orthod. 2001;71(2):116-9.

11. Levine RS. Briefing paper: oral aspects of dummy and digit sucking. Br Dent J. 1999;186(3):108.

12. Lindner A. Longitudinal study on the effect of early interceptive treatment in 4-year-old children with unilateral cross-bite. Scand J Dent Res. 1989;97(5):432-8.

13. Lindner A, Modéer T. Relation between sucking habits and dental characteristics in preschoolchildren with unilateral cross-bite. Scand J Dent Res. 1989;97(3):278-83. with pacifier-sucking habits that persisted until 2 years of age or beyond.

2. Parents should be instructed to help their children control the pacifier-sucking habit by the age of 2 years in order to prevent the potential development of transverse malocclusions.

14. Malandris M, Mahoney EK. Aetiology, diagnosis and treatment of posterior cross-bites in the primary dentition. Int $\mathrm{J}$ Paediatr Dent. 2004;14(3):155-66.

15. Mercadante MMN. Hábitos em Ortodontia. In: Vellini-Ferreira F. Ortodontia: diagnóstico e planejamento Clínico. $5^{\mathrm{a}}$ ed. São Paulo: Artes Médicas; 2002. p. 253-79.

16. Modéer T, Odenrick L, Lindner A. Sucking habits and their relation to posterior cross-bite in 4-year-old children. Scand J Dent Res. 1982;90(4):323-8.

17. Ogaard B, Larsson E, Lindsten R. The effect of sucking habits, cohort, sex, intercanine arch widths, and breast or bottle feeding on posterior crossbite in Norwegian and Swedish 3-year-old children. Am J Orthod Dentofacial Orthop. 1994;106(2):161-6.

18. Schopf P. Indication for and frequency of early orthodontic therapy or interceptive measures. J Orofac Orthop. 2003;64(3):186-200.

19. Thilander B, Wahlund S, Lennartsson B. The effect of early interceptive treatment in children with posterior cross-bite. Eur J Orthod. 1984;6(1):25-34.

20. Victora CG, Behague DP, Barros FC, Olinto MTA, Weiderpass E. Pacifier use and short breastfeeding duration: cause, consequence, or coincidence? Pediatrics. 1997;99(3):445-53.

21. Viggiano D, Fasano D, Monaco G, Strohmenger L. Breast feeding, bottle feeding, and non-nutritive sucking; effects on occlusion in deciduous dentition. Arch Dis Child. 2004;89(12):1121-3.

22. Warren JJ, Bishara SE. Duration of nutritive and nonnutritive sucking behaviors and their effects on the dental arches in the primary dentition. Am J Orthod Dentofacial Orthop. 2002;121(4):347-56.

23. Warren JJ, Bishara SE, Steinbock KL, Yonezu T, Nowak AJ. Effects of oral habits' duration on dental characteristics in the primary dentition. J Am Dent Assoc. 2001;132(12):168593.

24. Zardetto CGC, Rodrigues CRMD, Stefani FM. Effects of different pacifiers on the primary dentition and oral myofunctional structures of preschool children. Pediatr Dent. 2002;24(6):552-60. 